Info Artikel Diterima Juli 2017

Disetujui Januari 2018

Dipublikasikan April 2019

\title{
ANALISIS PENDAPATAN PETERNAKAN AYAM BROILER POLA KEMITRAAN DI KECAMATAN GUNUNG PATI SEMARANG
}

\author{
Income Analysis Of Chicken Broiler Livestock With Partner In \\ Gunungpati Subdistrict Semarang City
}

\author{
N. P. Cahyaningtyas, E. Prasetyo dan W. Sarengat \\ Departemen Peternakan Fakultas Peternakan dan Pertanian \\ Universitas Diponegoro
}

Email :nandaputri.np94@gmail.com

\begin{abstract}
ABSTRAK
Penelitian ini bertujuan untuk mengidentifikasi penggunaan faktor-faktor produksi (meliputi jumlah DOC, pakan ternak, tenaga kerja, listrik dan vaksin) menghitung biaya, penerimaan, dan pendapatan serta, menganalisis pengaruh faktor-faktor produksi terhadap pendapatan usaha ternak ayam broiler pola kemitraan di Kecamatan Gunungpati Kota Semarang. Metode penelitian yang digunakan adalah survey. Survey yaitu penelitian yang mengambil sampel dari populasi dan menggunakan kuesioner sebagai alat pengumpulan data. Pengambilan sampel menggunakan Random Sampling dan pengumpulan data dalam penelitian ini menggunakan observasi dan wawancara dengan bantuan kuisioner. Analisis pengujian ini dilakukan dengan uji regresi linier berganda. Hasil dari penelitian menunjukkan biaya produksi paling tinggi diperoleh peternak dari PT Mustika yaitu sebesar Rp.1.603.339.108,- per seribu ekor, PT Malindo Rp. 148.813.906,- per seribu ekor, PT Umi Perkasa Rp. 170.429.177,- per seribu ekor, PT HBS Rp. 67.759.535,-- per seribu ekor. Sedangkan jumlah pendapatan tertinggi di peroleh peternak PT Mustika sebesar Rp. 275.497.310,- sedangkan pendapatan terendah diperoleh peternak PT Malindo sebesar Rp. 242.293.518,-Secara keseluruhan rerata pendapatan per tahun peternak di Kecamatan Gunungpati mencapai $\mathrm{Rp}$ 266.876.566,-. Secara serempak variabel-variabel jumlah DOC, tenaga kerja, pakan, listrik dan vaksin berpengaruh signifikan terhadap variabel dependen pendapatan. Secara parsial hanya variabel jumlah DOC yang berpengaruh signifikan terhadap variabel pendapatan. Sedangkan variabel tenaga kerja, pakan, listrik dan vaksin berpengaruh tidak signifikan terhadap variabel pendapatan.
\end{abstract}

Kata kunci : Ayam broiler, Biaya Produksi, Pendapatan.

\section{ABSTRACT}

This study aims to identify the use of factors of production (including the number of DOC, animal feed, labor, electricity and vaccines) to calculate costs, revenue, and income as well as, to analyze the influence of production factors on 
broiler livestock income in partnership pattern in Gunungpati Subdistrict Semarang City. The research method used is survey. Survey is a study that takes a sample of the population and uses the questionnaire as a means of data collection. Sampling using Random Sampling and data collection in this study using observations and interviews with the help of questionnaires. Analysis of this test is done by multiple linear regression test. The result of research shows that the highest production cost is obtained from PT Mustika that is Rp. 1.603.339.108, per thousand of tails, PT Malindo Rp. 148,813,906, - per thousand of tails, PT Umi Perkasa Rp. 170.429.177, - per thousand head, PT HBS Rp. 67.759.535, - per thousand tails. While the highest revenue earned by PT Mustika breeder is Rp. 275,497,310, - while the lowest income is obtained by PT Malindo breeder of Rp. 242.293.518, -. Overall the average annual income of farmers in Gunungpati Subdistrict reached Rp 266.876.566, -. Simultaneously the variables of DOC, labor, feed, electricity and vaccine have a significant effect on income dependent variable. Partially only variable amount of DOC which have significant effect to income variable. While variable of labor, feed, electricity and vaccine have no significant effect to income variable.

\section{Keywords: Broiler Chicken, Production Cost, Revenue}

\section{PENDAHULUAN}

Usaha peternakan ayam pedaging (broiler) merupakan salah satu usaha yang berpotensi menghasilkan daging dan meningkatkan konsumsi protein bagi masyarakat. Ayam pedaging merupakan ayam yang tumbuh dengan cepat dan dapat dipanen dalam waktu beberapa minggu. Pengembangan usaha peternakan dengan pola kemitraan Perusahaan Inti Rakyat antara industri peternakan (perusahaan) sebagai inti dengan peternak sebagai plasma merupakan bentuk kerjasama yang saling menguntungkan dan mempercepat pencapaian target pembangunan sub sektor peternakan yang merupakan bagian dari tujuan pengembangan wilayah (Siagian, 2011). Peranan perusahaan besar sebagai mitra pada peternakan rakyat diharapkan dapat menjamin kepastian pasokan sarana produksi dan harga jual produk, serta adanya jaminan pasar atas produk yang dihasilkan. Pola kemitraan dapat digunakan untuk mengatasi berbagai macam kekurangan yang dihadapi oleh peternak rakyat. Kemitraan adalah kerjasama bidang usaha budidaya ayam ras antar peternak rakyat dengan perusahaan peternakan atau perusahaan dibidang peternakan. Tujuan dilakukan pola kemitraan adalah untuk memperkecil resiko usaha terutama peternak rakyat sebagai mitra usaha plasma, karena dijaminnya sarana produksi (kuantitas, kualitas dan harga), pemasaran hasil dan jaminan pendapatan oleh perusahaan peternakan atau perusahaan dibidang peternakan selaku mitra usaha inti. Sehingga akan mengurangi beban anggota dalam melakukan usahanya, antara lain: berkurangnya biaya yang dikeluarkan. Hal ini akan menyebabkan pendapatan anggota meningkat dan menguntungkan, oleh karena itu analisis pendapatan perlu dilakukan. Tujuan dari penelitian ini adalah untuk mengidentifikasi penggunaan faktor produksi (meliputi jumlah DOC, pakan ternak, tenaga kerja, listrik dan 
vaksin) pada usaha ternak ayam broiler pola kemitraan di Kecamatan Gunungpati, mengetahui atau menghitung biaya, penerimaan, dan pendapatan usaha ternak ayam broiler pola kemitraan, menganalisis pengaruh faktor-faktor produksi terhadap pendapatan usaha ternak ayam broiler.

\section{BAHAN DAN METODE}

Penelitian ini dilakukan pada bulan Juni-Juli 2016 di Kecamatan Gunungpati Kota Semarang, pada peternakan ayam broiler pola kemitraan. Metode penelitian yang digunakan adalah survey. Pengumpulan data menggunakan kuesioner dengan cara memberi seperangkat pertanyaan atau pertanyaan tertulis kepada para responden untuk dijawab (Sujarweni, 2014). Metode penentuan responden menggunakan metode simple random sampling sebanyak 32 sampel peternak dari 93 peternakan di Kecamatan Gunungpati.

Data yang dikumpulkan adalah data primer dan data sekunder. Data primer meliputi keadaan umum peternakan, tata laksana pemeliharaan, biaya produksi (biaya variabel dan biaya tetap), biaya pemasaran, volume penjualan, harga jual satuan produk, faktor produksi (jumlah DOC, penggunakan tenaga kerja, pakan obat-obatan dan vaksin). Data sekunder diperoleh dari suatu lembaga yang terkait dengan penelitian ini, seperti kantor kelurahan yang menyangkut data tentang keadaan umum daerah penelitian dan mitra dari peternakan yang bersangkutan.

Data yang diperoleh dari hasil pengamatan dan wawancara kemudian diolah secara deskriptif dan statistik. Semua data yang terkumpul selanjutnya ditabulasikan sesuai dengan masing-masing variabel kemudian dilakukan perhitungan variabel. Untuk mengetahui pengaruh variabel pendapatan menggunakan analisis Regresi Linier Berganda. Persamaan regresi linier berganda adalah sebagai berikut (Ghozali, 2016):



Untuk menunjukkan apakah semua variabel independen yang dimasukan dalam model mempunyai pengaruh secara serempak terhadap variabel dependen, dengan rumusnya adalah sebagai berikut :

$\mathrm{F}=\frac{R 2 / K}{(1-R 2)(N-K-1)}$ 
Keterangan:

$\mathrm{R}^{2} \quad$ : jumlah kuadrat regresi

$\mathrm{K} \quad$ : jumlah variabel

$1-\mathrm{R}^{2} \quad$ : jumlah kuadrat residual

Uji t digunakan untuk menguji signifikansi hubungan antara variabel $\mathrm{X}$ dan $\mathrm{Y}$, apakah variabel X (variabel dependen) benar-benar berpengaruh terhadap variabel Y (variabel independen) secara terpisah atau parsial (Ghozali, 2016) dengan rumus sebagai berikut :

$\mathrm{t}=\frac{b}{s b}$

Keterangan:

t $\quad$ : statistik uji

b : koefisien regresi

$\mathrm{Sb} \quad$ : simpangan baku

\section{HASIL DAN PEMBAHASAN}

\section{Bibit}

DOC yang dipelihara oleh para peternak di Kecamatan Gunungpati diperoleh dari pihak inti yang menaungi. Jenis DOC yang digunakan tiap inti juga berbeda-beda tergantung dari jenis strain yang dihasilkan oleh setiap perusahaan inti, hal ini dikarenakan perusahaan inti yang menaungi peternak di Kecamatan Gunungpati. Secara keseluruhan jenis strain DOC yang digunakan merupakan jenis strain Cobb. Pertimbangan penggunaan bibit Cobb adalah faktor pertumbuhan ayam yang cukup baik sehingga lama pemeliharaannya lebih singkat dan mempunyai ketahanan terhadap penyakit yang cukup baik. Menurut Tamalluddin (2014), pemilihan DOC yang baik juga mempertimbangkan persentase kematian yang rendah, konversi pakan yang rendah, mampu menyesuaikan diri dengan lingkungannya sehingga tidak mudah stres, dan resisten terhadap penyakit. Jumlah DOC yang dikirimkan kepada peternak plasma disesuaikan dengan kapasitas kandang yang dimiliki dan kesepakatan kontrak yang sudah terjalin sebelumnya.

\section{Perkandangan}

Bentuk kandang memiliki bentuk banyak model dengan biaya pembuatan yang bervariasi, tergantung jenis kandangnya. Konstruksi kandang harus disesuaikan dengan keadaan lokasi. Gambaran kandang yang terdapat di Kecamatan Gunungpati sesuai dengan Tamaluddin (2014) adalah sebagai berikut

1. Kandang bisa berupa kandang postal, panggung, ataupun kombinasi keduanya. Pemeliharaan broiler dengan tujuan panen muda (22-24 hari) akan lebih efisien menggunakan kandang postal atau tingkat.

2. Dinding kandang menggunakan bambu atau kawat

3. Kemiringan atap baik 
4. Arah kandang membujur Barat-Timur agar kandang mendapatkan sinar matahari yang cukup, tetapi tidak langsung mengenai ayam.

5. Ukuran kandang disesuaikan dengan jumlah ayam yang akan diproduksi. Bila panen direncanakan pada umur 22-24 hari dengan kisaran bobot badan 0,9 sampai $1,2 \mathrm{~kg}$, kepadatan yang bisa diterapkan adalah $1: 10$ (10 ekor/m2)

6. Bahan atap dari asbes atau genteng yang disesuaikan dengan lokasi kandang, ketersediaan bahan, dan ketersediaan dana.

\section{Pemberian Pakan dan Minum}

Pembersihan pakan yang dilakukan para peternak disesuaikan dengan fase pertumbuhan yaitu fase starter (umur kurang dari 4 minggu) dan fase finisher (lebih dari 4 minggu). Pakan yang diberikan oleh peternak pada periode starter berbeda-beda sesuai dengan yang diberikan oleh perusahaan inti. PT. Malindo menggunakan pakan jenis 9202, PT. Mustika menggunakan pakan jenis B 11 B, PT. Umi Perkasa menggunakan pakan jenis Bravo type 510 dan HBS menggunakan pakan jenis BR 1 semuanya dalam bentuk crumble. Periode finisher pun berbeda-beda sesuai dengan perusahaan inti. PT. Malindo menggunakan pakan jenis 9203, PT. Mustika menggunakan pakan jenis B 11 B, Bareta menggunakan pakan jenis Bravo type 510, PT. Serat menggunakan pakan jenis BR 2 dan BOJ menggunakan pakan jenis B 11 dalam bentuk pellet.

\section{Pencegahan Penyakit}

Pencegahan penyakit yang dilakukan oleh para peternak plasma di Kecamatan Gunungpati adalah dengan melakukan sanitasi kandang maupun peralatan, vaksinasi, menjalankan program obat yang telah ditentukan oleh pihak inti, dan isolasi pada ayam yang terserang penyakit. Cara kerja dalam pemberian vaksin yaitu pertama-tama giring seluruh ayam kesuatu sudut kandang, lalu beri sekat. Kemudian teteskan vaksin pada ayam satu per satu. Simpan ayam yang sudah diberi vaksin di bagian sekat yang kosong. Usahakan vaksin yang digunakan selalu dalam keadaan dingin sampai vaksinisasi selesai (Sonarwiyo dan Deafania, 2015). Cara pemberian vaksin dapat melalui tetes mata, tetes hidung, air minum, injeksi intramuscular (daging) dan subkutan (bawah kulit), tusuk sayap, dan sprayer. Aplikasi vaksinasi berupa tetes mata dilakukan pada umur empat hari untuk mencegah penyakit ND (Newcastle Diseases). Vaksinasi melalui air minum mencegah penyakit gumboro atau IBD (9-12 hari) dan ND (17-21 hari).

\section{Kemitraan}

Wilayah Kecamatan Gunungpati, usaha ayam broiler dilakukan dengan pola kemitraan, yaitu peternak berkerja sama dengan perusahaan peternakan sebagai mitra yang kemudian disebut inti. Data Dinas Peternakan dan Perikanan Kota Semarang 2016, sebagian besar di wilayah Kecamatan Gunungpati perusahaan inti yang paling banyak menjalin mitra dengan peternak adalah PT. Mustika. Kondisi tersebut berbeda pada saat dilakukan survei penelitian, hal ini disebabkan beberapa peternak yang pindah ke perusahaan ini lain seperti PT. Malindo. Peternak tersebut beralih ke perusahan inti lain karena pada beberapa 
periode pemeliharaan terakhir pendapatan peternak mengalami penurunan terus menerus, hal ini disebabkan performance dari ayam yang dipelihara tidak bisa berproduksi optimal yaitu bobot badan rendah dan tingkat mortalitas yang tinggi.

\section{Biaya Produksi}

Biaya produksi yang dikeluarkan peternak broiler plasma dari biaya tetap dan biaya variabel. Biaya tetap yang dikeluarkan peternak broiler plasma secara langsung adalah sewa lahan dan biaya tetap yang tidak langsung nyata dikeluarkan peternak adalah penyusutan kandang dan peralatan. Biaya variabel yang dikeluarkan peternak broiler plasma adalah biaya pembelian DOC, pakan, vaksin, dan obat, sekam, grajen, gula, koran, upah tenaga kerja dan retribusi.

Biaya produksi yang dikeluarkan oleh peternak plasma terdiri dari biaya tetap dan biaya variabel. Perhitungan biaya produksi secara rinci dapat dilihat pada Tabel 1 dan Tabel 2.

Tabel 1. Biaya Produksi Usaha Peternakan Ayam Broiler PT Mustika dan PT Malindo Selama Satu Tahun

\begin{tabular}{|c|c|c|c|c|c|}
\hline \multirow{2}{*}{ No. } & \multirow{2}{*}{ Biaya Produksi } & \multicolumn{2}{|c|}{ PT Mustika } & \multicolumn{2}{|c|}{ "PT Malindo } \\
\hline & & Jumlah & Persentase & Jumlah & Persentase \\
\hline & & ---Rp--- & $---\%---$ & ---Rp--- & $---\%---$ \\
\hline 1. & Total Biaya Tetap & 293.074 .800 & 100,00 & 111.793 .100 & 100,00 \\
\hline \multirow[t]{9}{*}{2.} & Biaya Variabel & & & & \\
\hline & Bibit & 3.814 .650 .000 & 17,94 & 1.330 .050 .000 & 17,11 \\
\hline & Pakan & 15.698 .053 .373 & 76,78 & 5.992 .804 .458 & 77,08 \\
\hline & OVK & 314.198 .671 & 1,54 & 118.748 .111 & 1,53 \\
\hline & Listrik & 27.231 .449 & 0,13 & 10.665 .094 & 0,14 \\
\hline & Tenaga Kerja & 308.167 .650 & 1,43 & 116.400 .644 & 1,50 \\
\hline & Retribusi & 38.250 .000 & 0,18 & 14.250 .000 & 0,18 \\
\hline & Total Biaya Variabel & 20.631 .178 .893 & 100,00 & 7.774.897.487 & 100,00 \\
\hline & Total Biaya Produksi & 20.924 .253 .693 & & 7.886 .690 .587 & \\
\hline
\end{tabular}

Sumber : Data primer yang diolah (2016).

Berdasarkan data pada Tabel 1 menunjukkan bahwa peternak dari PT Mustika mengeluarkan biaya produksi yang lebih tinggi dibanding seluruh perusahaan inti yang lain dengan nilai Rp 20.924.253.693 yang terdiri dari 17 kelompok peternak dan setiap peternak mengeluarkan biaya produksi sebesar Rp. 1.230.838.452,- per peternak dan biaya produksi per seribu ekor sebesar Rp. 1.603.339.108,- , kemudian disusul oleh PT Malindo dengan Rp 7.886.690.587 yang terdiri dari 7 kelompok peternak dan setiap peternak mengeluarkan biaya produksi sebesar Rp. 1.126.658.512,- per peternak sedangkan biaya produksi per seribu ekor sebesar Rp. 148.813.906,-, PT Umi Perkasa dengan Rp 6.220.664.990 yang terdiri dari 5 kelompok peternak dan setiap peternak mengeluarkan biaya produksi sebesar Rp. 1.244.132.998,-- per peternak sedangkan biaya produksi per seribu ekor sebesar Rp. 170.429.177,- dan PT HBS dengan Rp 846.994.193 yang terdiri dari 2 kelompok peternak dan setiap peternak mengeluarkan biaya produksi 
sebesar Rp. 423.497.096,-- per peternak sedangkan biaya produksi per seribu ekor sebesar Rp. 67.759.535 .

Tabel 2. Biaya Produksi Usaha Peternakan Ayam Broiler PT Umi Perkasa dan PT HBS Selama Satu Tahun

\begin{tabular}{|c|c|c|c|c|c|}
\hline \multirow{2}{*}{ No. } & \multirow{2}{*}{ Biaya Produksi } & \multicolumn{2}{|c|}{ PT Umi Perkasa } & \multicolumn{2}{|c|}{ PTHBS } \\
\hline & & Jumlah & Persentase & Jumlah & Persentase \\
\hline & & ---Rp--- & $---\%---$ & ---Rp--- & $---\%---$ \\
\hline 1. & Total Biaya Tetap & 81.390 .050 & 100,00 & 33.632 .200 & 100,00 \\
\hline \multirow[t]{9}{*}{2.} & Biaya Variabel & & & & \\
\hline & Bibit & 1.029 .037 .500 & 16,76 & 396.500 .000 & 16,20 \\
\hline & Pakan & 4.777 .493 .330 & 77,82 & 1.922 .630 .742 & 78,56 \\
\hline & OVK & 94.858 .060 & 1,55 & 38.685 .468 & 1,58 \\
\hline & Listrik & 8.018 .502 & 0,13 & 3.524 .996 & 0,14 \\
\hline & Tenaga Kerja & 100.502 .892 & 1,64 & 32.955 .920 & 1,35 \\
\hline & Retribusi & 11.250 .000 & 0,18 & 4.500 .000 & 0,18 \\
\hline & Total Biaya Variabel & 6.139 .274 .940 & 100,00 & 813.361 .993 & 100,00 \\
\hline & Total Biaya Produksi & 6.220 .664 .990 & & 846.994 .193 & \\
\hline
\end{tabular}

Sumber : Data primer yang diolah (2016).

Berdasarkan Tabel 1. diketahui bahwa biaya tetap terdiri dari penyusutan kandang, peralatan dan pajak bumi. Biaya tetap peternakan ayam pedaging di Kecamatan Gunungpati oleh perusahaan inti PT Mustika, PT Malindo, PT Umi Perkasa dan PT HBS secara berturut turut adalah Rp. 293.074.800; Rp. 111.793.100; Rp. 81.390.050 dan Rp. 33.632.200. Variabel terbesar dalam penyerapan biaya tetap dikeluarkan oleh biaya penyusutan kandang dengan rerata persentase $71,18 \%$.

Rata-rata biaya yang dikeluarkan untuk pakan oleh peternak plasma PT Mustika yaitu sebesar Rp.15.698.053.373,- (76,78\% dari total biaya produksi). Rata-rata biaya yang dikeluarkan untuk pakan oleh peternak plasma Malindo yaitu sebesar Rp5.992.804.458,- (77,08\% dari total biaya produksi). Rata-rata biaya yang dikeluarkan untuk pakan oleh peternak plasma PT Umi Perkasa yaitu sebesar Rp.4.777.493.330,- (77,82\% dari total biaya produksi). Rata-rata biaya yang dikeluarkan untuk pakan oleh peternak plasma PT HBS yaitu sebesar Rp.1.922.630.742,- (78,56\% dari total biaya produksi). Pembelian pakan akan menyumbangkan nilai terbesar karena pakan sebagai kebutuhan pokok ayam pedaging dan jumlahnya pun sebanding dengan jumlah ayam yang diternak/dimiliki oleh peternak.

\section{Penerimaan dan Pendapatan}

Penerimaan usaha ternak ayam ras pedaging merupakan total hasil yang diperoleh peternak dari hasil pemeliharaan ternak ayam ras pedaging selama satu periode. Hal ini sesuai dengan pernyataan Rasyaf (2002) dalam Rahmah (2015) apabila hasil produksi peternakan dijual ke pasar atau ke pihak lain, maka diperoleh sejumlah uang sebagai produk yang terjual tersebut. Besar atau kecilnya 
uang diperoleh tergantung dari pada jumlah barang dan nilai barang yang dijual. Barang yang dijual akan bernilai tinggi bila permintaan melebihi penawaran atau produksi sedikit. Besarnya rata-rata penerimaan peternak plasma di Kecamatan Gunungpati dapat dilihat pada Tabel 3 dan Tabel 4.

Tabel 3. Penerimaan Usaha Peternakan Ayam Broiler PT Mustika dan PT Malindo

\begin{tabular}{|c|c|c|c|c|c|}
\hline \multirow{2}{*}{ No. } & \multirow{2}{*}{ Penerimaan } & \multicolumn{2}{|c|}{ PT Mustika } & \multicolumn{2}{|c|}{ PT Malindo } \\
\hline & & Jumlah & Persentase & Jumlah & Persentase \\
\hline & & ---Rp--- & ---\%--- & ---Rp--- & $---\%$ \\
\hline 1. & $\begin{array}{l}\text { Penjualan } \\
\text { Ayam }\end{array}$ & 1.521 .172 .457 & 98,57 & 1.264 .473 .347 & 98,71 \\
\hline 2. & $\begin{array}{l}\text { Subsidi } \\
\text { Prestasi }\end{array}$ & 8.141 .099 & 0,53 & 6.098 .698 & 0,48 \\
\hline 3. & $\begin{array}{l}\text { Subsidi } \\
\text { Pasar }\end{array}$ & 6.605 .806 & 0,43 & 4.580 .169 & 0,36 \\
\hline 4. & Kotoran & 3.778 .000 & 0,24 & 3.044 .000 & 0,24 \\
\hline 5. & Karung & 3.492 .354 & 0,23 & 2.793 .188 & 0,22 \\
\hline & Total & 1.543 .189 .717 & 100,00 & 1.280 .989 .403 & 100,00 \\
\hline
\end{tabular}

Sumber: Data primer yang diolah (2017).

Tabel 4. Penerimaan Usaha Peternakan Ayam Broiler PT Umi Perkasa dan PT HBS.

\begin{tabular}{|c|c|c|c|c|c|}
\hline \multirow{2}{*}{ No. } & \multirow{2}{*}{ Penerimaan } & \multicolumn{2}{|c|}{ PT Umi Perkasa } & \multicolumn{2}{|c|}{ PTHBS } \\
\hline & & Jumlah & Persentase & Jumlah & Persentase \\
\hline & & ---Rp--- & ---\%--- & ---Rp--- & ---\%--- \\
\hline 1. & $\begin{array}{l}\text { Penjualan } \\
\text { Ayam }\end{array}$ & 1.403 .621 .823 & 98,61 & 622.238 .002 & 98,56 \\
\hline 2. & $\begin{array}{l}\text { Subsidi } \\
\text { Prestasi }\end{array}$ & 7.813 .345 & 0,55 & 3.303 .090 & 0,52 \\
\hline 3. & Subsidi Pasar & 5.620 & $0, ?$ & 15 & 0,45 \\
\hline 4. & Kotoran & 3.340 .000 & 0,23 & 1.539 .000 & 0,24 \\
\hline 5. & Karung & 2.951 .762 & 0,21 & 1.371 .336 & 0,22 \\
\hline & Total & 1.423 .347 .864 & 100,00 & 631.322 .743 & 100,00 \\
\hline
\end{tabular}

Sumber : Data primer yang diolah (2017).

Berdasarkan data yang disajikan pada Tabel 2. menunjukkan bahwa peternak plasma PT Mustika memperoleh rata-rata penerimaan paling tinggi dalam setahun yaitu sebesar Rp.1.543.189.717, dengan aspek penerimaan terbesar dari perusahaan inti lain melalui penjualan ayam, subsidi prestasi dan penjualan karung. Tingginya penerimaan ini disebabkan oleh jumlah populasi ternak PT Mustika yang lebih besar (8.692 ekor) dibanding perusahaan inti lain. Banyaknya populasi ayam yang dipelihara juga akan berpengaruh terhadap hasil kotoran dan karung bekas pakan. Penerimaan yang diperoleh tergantung dari jumlah produk yang dihasilkan dan harga produk. Secara keseluruhan aspek penjualan produk 
utama berupa ayam menjadi penyumbang terbesar dari total nilai penerimaan dengan rerata 98,62\%, kemudian disusul oleh subsidi prestasi dengan 0,52\%, subsidi pasar dengan $0,40 \%$, penjualan karung $0,24 \%$ dan penjualan kotoran dengan $0,22 \%$. Rata-rata pendapatan peternak plasma di Kecamatan Gunung Patidapat dilihat pada Tabel 3.

Tabel 3. Pendapatan Peternak Plasma Selama Satu Tahun

\begin{tabular}{|c|c|c|c|c|c|}
\hline $\begin{array}{c}\text { No } \\
\text {. }\end{array}$ & $\begin{array}{l}\text { Perusahaan } \\
\text { Inti }\end{array}$ & $\begin{array}{l}\text { Rata-rata } \\
\text { Populasi }\end{array}$ & Penerimaan & Biaya Produksi & Pendapatan \\
\hline & & --Ekor-- & \multicolumn{3}{|c|}{--------------------Rp-------------------- } \\
\hline 1. & PT Mustika & 44.482 & 1.543.189.717 & 1.267.692.407 & 275.49 \\
\hline 2. & PT Malindo & 35.801 & 1.280 .989 .403 & 1.038 .695 .885 & 242.293 .518 \\
\hline & PT $\quad$ Umi & & & & \\
\hline 3. & Perkasa & 39.327 & 1.423 .347 .864 & 1.160 .25 & 263.094 .161 \\
\hline 4. & PT HBS & 28200 & 1.578 .306 .857 & 1.291 .685 .582 & 286.621 .275 \\
\hline & rerata & 34427 & $1.456,458,460$ & 1.189 .581 .894 & 266.876 .566 \\
\hline
\end{tabular}

Sumber : Data primer yang diolah (2015).

Berdasarkan Tabel 3. dapat dilihat bahwa pendapatan paling tinggi diperoleh peternak dari PT Mustika yaitu sebesar Rp.275.497.310,--, sedangkan pendapatan yang paling rendah diperoleh peternak dari PT Malindo dengan nilai Rp. 242.293.518,-. Hal ini disebabkan faktor kepemilikan ternak oleh peternak PT Mustika lebih tinggi dibanding perusahaan lain dengan 44.482 ekor. Secara keseluruhan rerata pendapatan pertahun peternak di Kecamatan Gunungpati mencapai Rp 266.876.566. Hasil ini menunjukkan bahwa tingkat kematian untuk tiap periode berperan penting dalam menghasilkan pendapatan karena tingkat kematian menunjukkan jumlah populasi yang akan dipanen.

\section{Pengujian Regresi Linier Berganda}

Berdasarkan hasil Analisis Linear Berganda antara pendapatan usaha ayam broiler (Y) dengan variabel-variabel yang mempengaruhinya, yaitu jumlah DOC $\left(\mathrm{X}_{1)}\right.$, tenaga kerja $\left(\mathrm{X}_{2}\right)$, pakan $\left(\mathrm{X}_{3}\right)$, listrik $\left(\mathrm{X}_{4}\right)$ dan vaksin $\left(\mathrm{X}_{5}\right)$ didapat persamaan regresi linear berganda yang dapat ditulis sebagai berikut:

\section{$Y=39.800 .000+0,820 X_{1}+2,362 X_{2}+0,001 X_{3}+11,139 X_{4}-0,366 X_{5}+e$}

Berdasarkan persamaan regresi tersebut diatas, maka dapat di jelaskan bahwa :

1. jumlah DOC meningkat 1 ekor maka akan meningkatkan pendapatan usaha ayam broiler sebesar $\mathrm{Rp} 0,820$. Hal ini sesuai dengan penelitian Fitriza, et al., (2012) bahwa tingkat pendapatan yang diperoleh peternak plasma ayam pedaging akan semakin meningkat seiring dengan peningkatan jumlah ternak ayam pedaging.

2. Koefisien regresi untuk tenaga kerja adalah 2,362 hal ini berarti bahwa jika tenaga kerja meningkat 1 orang maka akan meningkatkan pendapatan usaha ayam. Hal ini sesuai dengan penelitian Nurjana, et al., (2015) bahwa 
tenaga kerja berpengaruh signifikan positif terhadap pendapatan ayam broiler. Tenaga kerja usaha peternakan keluarga bisanya terdiri atas peternak beserta keluarga dan tenaga kerja dari luar yang semuanya berperan dalam usaha peternakan.

3. Koefisien regresi untuk pakan adalah 0,001 hal ini berarti bahwa jika pakan meningkat $1 \mathrm{~kg}$ maka akan meningkatkan pendapatan usaha ayam broiler sebesar Rp 0,001. Hal ini sesuai dengan penelitian Nurjana, et al., (2015) bahwa pakan berpengaruh signifikan terhadap pendapatan ayam broiler. Kualitas dan kuantitas pakan fase starter adalah kualitas atau kandungan zat gizi pakan yang terdiri dari protein 22 hingga 24 persen, lemak 2,5 persen, serat kasar empat persen, Kalsium (Ca) satu persen, Phospor (P) 0,7 hingga 0,9 persen, dan ME 2800 hingga $3500 \mathrm{Kcal}$.

4. Koefisien regresi untuk listrik adalah 11,139 hal ini berarti bahwa jika listrik meningkat $\mathrm{Rp}$ 1,00 maka akan meningkatkan pendapatan usaha ayam broiler sebesar Rp 11,139.

5. Koefisien regresi untuk vaksin adalah $-0,366$ hal ini berarti bahwa jika vaksin meningkat 1 unit maka akan menurunkan pendapatan usaha ayam broiler sebesar Rp 0,366. Hal ini sesuai dengan penelitian Nurjana, et al., (2015) bahwa vaksin berpengaruh signifikan negatif terhadap pendapatan ayam broiler. Vaksinasi pada ayam sangat diperlukan karena vaksinasi merupakan salah satu program pencegahan yang sangat efektif.

\section{KESIMPULAN DAN SARAN}

Berdasarkan hasil penelitian yang dilakukan dapat disimpulkan bahwa secara serempak variabel-variabel independen jumlah DOC, tenaga kerja, pakan, listrik dan vaksin (berpengaruh signifikan terhadap variabel dependen pendapatan. Secara parsial hanya variabel jumlah DOC yang berpengaruh signifikan terhadap variabel dependen pendapatan. Sedangkan variabel tenaga kerja, pakan, listrik dan vaksin tidak berpengaruh signifikan terhadap variabel dependen pendapatan. Jumlah biaya produksi pada penelitian ini yakni, PT Mustika mengeluarkan biaya produksi yang lebih tinggi dibanding seluruh perusahaan inti yang lain dengan nilai Rp 20.924.253.693 yang terdiri dari 17 kelompok peternak dan setiap peternak mengeluarkan biaya produksi sebesar Rp. 1.230.838.452,- per peternak dan biaya produksi per seribu ekor sebesar Rp. 1.603.339.108,-, kemudian disusul oleh PT Malindo dengan Rp 7.886.690.587 yang terdiri dari 7 kelompok peternak dan setiap peternak mengeluarkan biaya produksi sebesar Rp. 1.126.658.512,- per peternak sedangkan biaya produksi per seribu ekor sebesar Rp. 148.813.906,-, PT Umi Perkasa dengan Rp 6.220.664.990 yang terdiri dari 5 kelompok peternak dan setiap peternak mengeluarkan biaya produksi sebesar Rp. 1.244.132.998,- per peternak sedangkan biaya produksi per seribu ekor sebesar Rp. 170.429.177,- dan PT HBS dengan Rp 846.994.193 yang terdiri dari 2 kelompok peternak dan setiap peternak mengeluarkan biaya produksi sebesar Rp. 423.497.096,- per peternak sedangkan biaya produksi per seribu ekor sebesar Rp. 67.759.535,-. Jumlah pendapatan paling tinggi diperoleh peternak dari PT Mustika yaitu sebesar Rp.275.497.310,-, sedangkan pendapatan yang paling rendah diperoleh peternak dari PT Malindo dengan nilai Rp. 242.293.518,-. 
Peternak ayam broiler dapat lebih menekan biaya produksi agar pendapatan yang diperoleh dapat lebih maksimal. Peternak broler plasma agar lebih kritis terhadap kontrak kerjasama yang ditawarkan oleh pihak inti, apakah standar yang ditentukan realistis dengan kemampuan peternak sehingga peternak tidak dirugikan di kemudian hari.

\section{DAFTAR PUSTAKA}

Fitriza, Y.T., F.T. Haryadi, dan S. P. Syahlani. 2012. Analisis Pendapatan dan Persepsi Peternakan Plasma Terhadap Kontrak Perjanjian Pola Kemitraan Ayam Pedaging di Propinsi Lampung. Buletin Peternakan 36(1): 57-65.

Ghozali, Imam. 2016. Aplikasi Analisis Multivariant Dengan Program IBMS SPSS 23 Edisi 7. Universitas Diponegoro. Semarang.

Rahmah, Laela. 2015. Analisis Pendapatan Usaha Ternak Ayam Ras Pedaging Pada Pola Usaha yang Berbeda di Kecamatan Cingambul Kabupaten Majalengka. Jurnal Ilmu Pertanian dan Peternakan. 3 (1) : 1-15.

Rasyaf, M. 2002. Beternak Ayam Pedaging. Edisi Revisi. Penebar Swadaya, Jakarta.

Santoso, Singgih. 2014. Statistik Multivariant Edisi Revisi. Elex Media Komputindo, Jakarta.

Siagian, Hanny. 2011. Kontribusi Usaha Peternakan Dalam Pengembangan Wilayah. Jurnal Wira Ekonomi Mikroskil. 1 (1) : 31-35.

Soenarwiyo, WS. dan Deafania. 2015. Kunci Sukses Budidaya Ayam Broiler 28 Hari Panen Besar. Araska, Yogyakarta.

Sujarweni, V. Wiratna. 2014. Metodologi Penelitian. Pustakabarupress, Yogyakarta.

Tamalluddin, F. 2015. Ayam Broiler 22 Hari Panen Lebih Untung. Penebar Swadaya, Jakarta. 